\title{
ANALISIS BENTUK LAYANAN HOMECARE YANG DIINGINKAN PASIEN BERDASARKAN KASUS PENYAKIT DI MASA PENDEMI COVID-19.
}

\section{ANALYSIS OF HOME CARE SERVICES AS PATIENT EXPECTATION DURING PANDEMIC OF COVID -19}

\author{
Christianto Nugroho $^{1 *}$, Suryono ${ }^{2}$, Bambang Wiseno ${ }^{3}$ \\ ${ }^{1,2,3}$ STIKes Pamenang \\ *Korespondensi Penulis : christiantonug@gmail.com
}

\begin{abstract}
Abstrak
Homecare merupakan pelayanan kesehatan di rumah yang memberikan kesempatan bagi masyarakat mendapatkan pelayanan kesehatan yang maksimal. Faktor kasus penyakit terhadap bentuk layanan homecare masih memerlukan analisis lebih mendalam. Tujuan dari penelitian ini adalah menganalisis kasus penyakit terhadap bentuk layanan homecare yang diinginkan pasien pada masa pendemi covid-19 di RS Kabupaten Kediri, Jawa Timur, Indonesia.

Desain penelitian ini menggunakan pendekatan cross-sectional. Populasi penelitian ini adalah semua pasien di RSUD Pare dan sampel penelitian 172 responden dengan tehnik simple random sampling pada bulan September 2020. Instrument penelitian ini menggunakan bentuk kuesioner yang berisi data diagnosa medis dan bentuk layanan homecare yang diinginkan oleh responden. Setelah data terkumpul diolah dan dianalisis dengan menggunakan SPSS 20 dan dilakukan uji statistik dengan crostab.

Hasil penelitian menunjukkkan bentuk layanan homecare berurutan sebagai berikut Perawatan 91 responden, pengobatan 54 respoden, konsultasi kesehatan 22 respoden, dan Fisoterapi 5 responden dari semua kasus penyakit yang dialami oleh pasien.

Bentuk layanan homecare dapat disimpulkan bahwa pelayanan keperawatan oleh tenaga perawat, pengobatan oleh dokter, konsultai kesehatan dan fisioterapi merupakan perpaduan yang harmonis untuk mewujudkan pelayana homecare yang baik dan servis yang memuaskan bagi masyarakat, sehingga kesehatan ditengah masyarakat bisa terwujud.
\end{abstract}

Kata kunci : Bentuk Layanan Homecare, Kasus Penyakit, Pasien

\begin{abstract}
Homecare is a health service at home that provides opportunities for the community to reach maximum health services. The factor of disease cases in the form of homecare services still requires more in-depth analysis. The purpose of this study was to analyze disease cases against the form of homecare services that patients expected during the COVID-19 pandemic at Kabupaten Kediri Hospital, Kediri, East Java, Indonesia. The design of this study was cross-sectional. The population of this study were all patients at RSUD Pare and the research sample was 172 respondents using simple random sampling technique. Collecting data with a questionnaire about the form of homecare services and cases of patient illness, then multivariate analysis was carried out with linear regression test. The results showed that the form of homecare services was sequentially as follows: Treatment of 91 respondents, treatment of 54 respondents, health consultation of 22 respondents, and Physiotherapy 5 respondents from all cases of disease experienced by patients. The form of homecare services can be concluded that nursing services by nurses, treatment by doctors, health consultants and physiotherapy are a harmonious combination to create good homecare services and satisfying services for the community, so that health in the community can be realized.
\end{abstract}

Keywords : Forms of Home Care Services, Disease Cases, Patients

Website : jurnal.stikespamenang.ac.di | Email : jurnal.pamenang@gmail.com 


\section{Pendahuluan}

Homecare adalah suatu bentuk layanan keperawatan $\mathrm{d}$ rumah yang berkesinambungan dan komporehensif yang diberikan kepada pasien maupun keluarga pasien yang bertujuan untuk memulihkan, mempertahankan dan meningkatkan kesehatan, serta mengoptimalkan kemandirian pasca perawatan di rumah sakit (Kausar, 2020).

Rumah sakit umum di wilayah pare yaitu RSUD Pare Kediri dengan rata-rata pasien: 14514 per tahun (Dinkes, 2018). Berdasarkan data yang ada di wilayah pare masih belum ada homecare yang beroperasi secara konsisten, baik swasta ataupun dibawah rumah sakit. Hal ini kurangnya analisis yang kuat untuk minat homecare di wilayah ini. Berdasarkan RISKESDAS (Riset Kesehatan Dasar) tahun 2013, kejadian penyakit tidak menular seperti hipertensi berjumlah 25,8\%, stroke 12,1\% dan Diabetes Melitus 2,1\% (Depkes RI, 2013). Penyakit yang memerlukan perawatan lama pada saat ini menimbulkan tantangan bagi dunia keperawatan untuk meningkatkan penyedia layanan keperawatan yang berkelanjutan. Perawatan yang berkelanjutan dalam hal ini adalah perawatan transisi, yaitu perawatan yang berfungsi untuk memanajemen pasien ketika di rumah sehingga proses perawatan tetap kontinuitas (Yuli Lestari, 2020).

Penyakit degeratif yang memerlukan perawatan yang relativ lama seperti kasus pasien pasca stroke yang mengalami komplikasi kelumpuhan dan memerlukan pelayanan rehabilitasi yang membtuhkan waktu relative lama, selain itu terjadinya transisi epidemilogi yang mengakibatkan kasus penyakit kronis diabndingkan penyakit akut, sehingga terjadi penngkatan jumlah kasus penyakit terminalyang tidak efektif dan efesien dirawat di rumah sakit, dengan demikian pelayanan homecare untuk menangani kasus seperti ini (Fahrepi et al., 2019).

Perawatan kesehatan di rumah yang merupakan salah satu bentuk pelayanan kesehatan adalah suatu komponen rentang pelayanan kesehatan yang berkesinambungan dan komprehensif diberikan kepada individu dan keluarga di tempat tinggal mereka yang bertujuan untuk meningkatkan, memepertahankan atau memulihkan kesehatan serta memaksimalkan tingkat kemandirian dan meminimalkan akibat dari penyakit termasuk penyakit terminal (Prasetyo, 2017).

Bentuk layanan yang diberikan homecare ke masyarakat samapai sekarang belum ada data ang pasti seberapa besar kebutuhan di masyarakat, maka peneliti tertarik meneliti tentang bentuk layanan homecare berdasarkan kasus penyakitnya.

\section{Metode}

Desain penelitian ini menggunakan pendekatan cross-sectional. Populasi penelitian ini adalah semua pasien di RSUD Pare dan sampel penelitian 172 responden dengan tehnik simple random sampling pada bulan September 2020. Instrument penelitian ini menggunakan bentuk kuesioner yang berisi data diagnosa medis dan bentuk layanan homecare yang diinginkan oleh responden. Setelah data terkumpul diolah dan dianalisis dengan menggunakan SPSS 20 dan dilakukan uji statistik dengan crostab.

\section{Hasil}

Tabel 1. Data Bentuk layanan Homecare yang diinginkan responden berdasarkan Kasus Penyakit

\begin{tabular}{|c|c|c|c|c|c|c|c|c|c|c|}
\hline \multirow{3}{*}{ Kas Prytat } & \multicolumn{8}{|c|}{ Be: Ly: Ly } & \multirow{2}{*}{\multicolumn{2}{|c|}{ Toul }} \\
\hline & \multicolumn{2}{|c|}{ Aamen } & \multicolumn{2}{|c|}{ Aagobsy } & \multicolumn{2}{|c|}{ Fivisungy } & \multicolumn{2}{|c|}{ 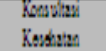 } & & \\
\hline & $?$ & $\%$ & $7(9)$ & $\%$ & $?(19)$ & $\%$ & $?(2)$ & $\%$ & ?(1) & $\%$ \\
\hline Diabsu Neinu & 21 & $23 \%$ & 4 & $\% \%$ & 0 & $\%$ & 3 & $14 \%$ & 28 & $16 \%$ \\
\hline 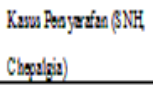 & 8 & $9 \%$ & 3 & $9 \%$ & 0 & $\%$ & 2 & $\%$ & 15 & $9 \%$ \\
\hline 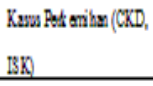 & 17 & $19 \%$ & 3 & $6 \%$ & 1 & $20 \%$ & 3 & $23 \%$ & 26 & $15 \%$ \\
\hline $\begin{array}{l}\text { Kass latag (CHI, } \\
\text { ANGNAHII) }\end{array}$ & 3 & $9 \%$ & 1 & $\%$ & 1 & $20 \%$ & 4 & $19 \%$ & 15 & $9 \%$ \\
\hline $\begin{array}{l}\text { Kass Pars -Phes } \\
\text { (Posumais TB, ALO) }\end{array}$ & 1 & $9 \%$ & 4 & $7 \%$ & 0 & $0 \%$ & 1 & $9 \%$ & 10 & $6 \%$ \\
\hline $\mathrm{Kas} R$ Rut Opari & 12 & $13 \%$ & 16 & $30 \%$ & 0 & $\%$ & 1 & $9 \%$ & 29 & $1 \% \%$ \\
\hline Kasoirdta & 10 & $11 \%$ & 4 & $\% \%$ & 1 & $20 \%$ & 0 & $0 \%$ & 15 & $9 \%$ \\
\hline Kass Gevisinatind & $?$ & $8 \%$ & 8 & $19 \%$ & 1 & $2 \%$ & 1 & $3 \%$ & 17 & $10 \%$ \\
\hline Kasalinge. & 6 & $\pi \%$ & 3 & $9 \%$ & 1 & $20 \%$ & 1 & $23 \%$ & 17 & $10 \%$ \\
\hline Toul & 91 & $100 \%$ & 94 & $100 \%$ & 1 & $100 \%$ & $n$ & $100 \%$ & $m$ & $100 \%$ \\
\hline
\end{tabular}

Berdasarkan data pada tabel 1. dalam tabulasi silang bentuk layanan homecare berdasarkan kasus penyakit klien ditemukan yang menginginkan bentuk layanan perawatan pada kasus Diabetes Melitus sebanyak (23\%) 21 responden, Perkemihan (19\%) 17 responden, Post operasi (13\%) 12 responden, 
yang paling rendah masing - masing kasus jantung dan paru (5\%) 5 responden. Sedangkan yang menginginkan bentuk layanan pengobatan meliputi Kasus post operasi (30\%) 16 respoden, gastrointestinal (15\%) 8 responden, yang paling rendah menginginkan pelayanan pengobatan adalah pada kasus perkemihan (6\%) 3 responden. Kemudian yang menginginkan bentuk layanan Fisioterapi masing- masing perkemihan dan kasus lainnya $(23 \%) 5$ responden dan yang terkecil Diabetes melitus, persyarafan, paruparu, post operasi dengan 0 responden dan yang menginginkan bentuk layanan kosultasi kesehatan terbanyak pada kasus post operasi (17\%) 29 responden, diabetes melitus (16\%) 28 responden, kasus perkemihan (15\%) 26 responden dan yang terkecil kasus paru paru (6\%) 10 responden.

Dari tabel 1. juga didapatkan sebaran yang diinginkan masyarakat akan bentuk layanan homecare berurutan sebagai berikut Perawatan 91 responden, pengobatan 54 respoden, konsultasi kesehatan 22 respoden, dan Fisoterapi 5 responden dari semua kasus penyakit yang dialami oleh pasien.

\section{Pembahasan}

Hasil penelitian diatas pada tabel 1 . menunjukkan bahwa dalam tabulasi silang bentuk layanan homecare berdasarkan kasus penyakit klien ditemukan bentuk layanan perawatan terbanyak pada kasus Diabetes melitus, bentuk layanan pengobatan pada kasus post operasi, bentuk layanan fisioterapi dengan kasus penyakit perkemihan dan yang menginginkan bentuk layanan konsultasi kesehatan adalah pada kasus post operasi.

Berdasarkan hasil ini memberikan gambaran bahwa bentuk layanan homecare yang diinginkan oleh masyarakat adalah perawatan, hal ini dikarenakan karena porses keperawatan tidak hanya berhenti di rumah sakit saja, banyak pasien dengan kasus penyakit yang masih membutuhkan perawatan di rumah secara intensive, apalagi ditengah pandemi covid-19 seperti saat ini, dimana kebanyakan dari masyarakat menghindari pelayanan kesehatan baik rumah sakit atau puskesmas. Masyarakat lebih memilih untuk tinggal dirumah dan dirawat di rumah, dengan pertimbangan bahwa mereka tidak menginginkan untuk tertular virus corona (Christianto Nugroho et al., 2020).
Kegiatan pelayanan kesehatan Home Care yang paling banyak diberikan oleh unit Home Care RS Kasih Ibu meliputi : pelayanan medis, pelayanan dan asuhan keperawatan, pemasangan atau penggantian alat kesehatan misalnya selang lambung, katheter, perawatan luka, pemberian obat melalui muskuler dan intravena (Vera Wilis Sedayu \& Mar'atus, 2020).

Bentuk layanan perawatan terbanyak pada kasus Diabetes Melitus dikarenakan jenis penyakit ini membutuhkan perawatan berkelanjutan dan proses yang lama untuk pasien dalam mengelola kasus penyakit Diabetes Melitus.

Manajemen diri pada pasien diabetes melits merupakan suatu pendekatan yang sangat efektif dalam mengelola kondisikondisi kronik. Manajemen diri sendiri memiliki lima domain utama meliputi manajemen nutrisi, olahraga dan aktivitas fisik, pengawasan glokosa darah, pengobatan medis dan perawatan kaki. Manajemen diri penderita DM yaitu bagaimana meningkatkan kontribusi dari lingkungan sekitar untuk berperan aktif dalam perawatan kesehatan pasien. Manajemen diri difokuskan pada keterlibatan semua sumber daya yang ada disekitar pasien sehingga akan lebih percaya diri dan meningkatkan perilaku dalam mengelola gejala, perawatan dan perubahan gaya hidup. Manajemen diri penderita DMT2 memiliki salah satu aspek penting yaitu pemecahan masalah yang berhubungan dengan cara dan waktu yang tepat dalam mengontrol kadar glukosa tubuh. Penderita yang mengetahui bahwa diabetes dapat menimbulkan komplikasi akan cenderung melakukan manajemen diri yang tinggi. Peranan faktor manajemen diri dalam memperoleh gula darah yang stabil pada penderita adalah hal yang cukup penting. Manajemen diri sendiri memiliki lima domain utama meliputi manajemen nutrisi, olahraga dan aktivitas fisik, pengawasan glukosa darah, pengobatan medis dan perawatan kaki (Haskas et al., 2020).

Prevalensi penyakit penyakit degeneratif semakin meningkat seperti stroke, diabetes melitus dan penyakit lainnya yang cenderng memerlukan waktu pengobatan dan rehabilitasi yang relativ lebih ama menyebabkan sebagian besar orang memilih homecare. Pelayanan kesehatan 
homecare ini dianggap sangat efektif dan efesien, karena bisa memberikan kesempatan pada anggota rumah tangga lainnya untuk tetap bisa melaksanakan tugas rutin mereka di rumah sambil menjaga pasien. Disamping itu lingkungan di rumah dirasakan lebih nyaman oleh sebagian besar pasien dibandingkan dengan rumah sakit, sehingga hal ini akan mempercepat kesembuhan mereka (Ma'mur, 2019) (C. Nugroho et al., 2020).

Bentuk layanan homecare dapat disimpulkan bahwa pelayanan keperawatan oleh tenaga perawat, pengobatan oleh dokter, konsultai kesehatan dan fisioterapi merupakan perpaduan yang harmonis untuk mewuudan pelayana homecare yang baik dan servis yang memuasakan bagi masyarakat, sehingga kesehatan ditengah masyarakat bisa terwujud.

\section{Kesimpulan}

Bentuk layanan homecare dapat disimpulkan bahwa pelayanan keperawatan oleh tenaga perawat, pengobatan oleh dokter, konsultai kesehatan dan fisioterapi merupakan perpaduan yang harmonis untuk mewujudkan pelayanan homecare yang baik dan servis yang memuaskan bagi masyarakat, sehingga kesehatan ditengah masyarakat bisa terwujud.

\section{Ucapan Terima Kasih}

Penulis mengucapkan terima kasih kepada pihak Rumah Sakit Umum Daerah Pare yang telah memberikan kesempatan dalam pengumpulan data penelitian di tengah pandemi covid-19.

\section{Daftar Pustaka}

Depkes RI. (2013). Riset Kesehatan Dasar. Jakarta: Badan Penelitian Dan Pengembangan Kesehatan Kementrian Kesehatan RI.

Dinkes. (2018). Profil Kesehatan Kabupaten Kediri. In Dinkes kabupaten kediri.

Fahrepi, R., Rate, S., \& Hadi, A. J. (2019). Hubungan Kualitas Pelayanan Homecare dengan tingkat Puskesmas Batua Kota Makassar The Relation Of Home Care Service Quality And Family 's Patient Statisfaction In Batua Public Health Center Jobs Area, Makassar City. PROMOTIF: Jurnal Kesehatan Masyarakat, 9(0451), 122 128.

https://jurnal.unismuhpalu.ac.id/index.php/P JKM/article/viewFile/589/482

Haskas, Y., Suarnianti, S., \& Restika, I. (2020). Efek Intervensi Perilaku Terhadap Manajemen Diri Penderita Diabetes Melitus
Tipe 2: Sistematik Review. Jurnal Kesehatan Andalas, $\quad 9(2), \quad 235$. https://doi.org/10.25077/jka.v9i2.1289

Kausar, L. I. E. (2020). Pemanfaatan Teknologi Informasi Berbasis Internet Terhadap Perkembangan Home Care Di Indonesia. Dinamika Kesehatan Jurnal Kebidanan Dan Keperawatan, 10(1), 212-223. https://doi.org/10.33859/dksm.v10i1.331

Ma'mur, W. D. M. S. A. (2019). Evaluasi Program Homecare Pada Puskesmas Bara-Baraya Kota Makassar. Jurnal Adminitrasi Negara, 25(2), 212-228. https://doi.org/https://doi.org/10.33509/jan.v $25 i 3.889$

Nugroho, C., Suryono, ., \& Wiseno, B. (2020). The Analysis of Homecare Interest in Pandemic Covid-19 Period Based on Disease Case in Indonesia. European Journal of Medical and Health Sciences, 2(5), 1-3. https://doi.org/10.24018/ejmed.2020.2.5.524

Nugroho, C., Suryono, S., \& Wiseno, B. (2020). Homecare Interest For Post Hospitalizing Patient In Pare Region. STRADA Jurnal Ilmiah Kesehatan, 9(2), 1101-1105. https://doi.org/10.30994/sjik.v9i2.450

Prasetyo, Y. B. (2017). Homecare Services' Potential at the UMM Hospital: Analysis on the Disease Cases, Public Social and Economy. Jurnal Keperawatan, 7(1), 70-78. https://doi.org/10.22219/jk.v7il.3921

Vera Wilis Sedayu, W., \& Mar'atus, M. (2020). Hubungan pelayanan home care metode $5 \mathrm{~m}$ dengan kepuasan keluarga pasien di unit home care rumah sakit kasih ibu surakarta. Jurnal Keperawatan, 42, 1-15. http://eprints.ukh.ac.id/id/eprint/102/1/publik asi.pdf

Yuli Lestari, I. S. P. (2020). Telehealth: Elektronik Housecall System, Solusi Mengurangi Biaya Perawatan Kesehatan. Jurnal Keperawatan, $\operatorname{XIII}(2)$, 244-248. https://doi.org/10.31220/osf.io/z5fbp 